\title{
ANALISIS PRODUKSI TEBU DAN GULA DI PT. PERKEBUNAN NUSANTARA VII (PERSERO)
}

\author{
Analysis of Sugarcane and Sugar Production in PT. Perkebunan Nusantara VII (PERSERO)
}

\author{
Derry Candia Apriawan ${ }^{1}$, Irham ${ }^{1}$, Jangkung Handoyo Mulyo ${ }^{1}$ \\ ${ }^{1}$ Fakultas Pertanian, Universitas Gadjah Mada
}

\begin{abstract}
The study was conducted in Bungamayang District PT. Perkebunan Nusantara VII (Persero), Lampung Province. The objective of this study are: (1) to see the trend of production, productivity and input use of sugarcane and sugar production, (2) to know factors affecting production of sugarcane, (3) to identify factors affecting production of sugar, and (4) to estimate the profit of sugar and molasses. The method used was descriptive quantitative analysis. Sampling location was determined by purposively. The data used are secondary data during 30 years (1984-2013). Trend analysis, multiple linear regression (Cobb-Douglas function), and profit analysis we used in this study. The results of trend analysis show that the production of sugar, sugar productivity, and rendemen has a positive trend, while the number of labour has a negative trend. The result of regression analysis shows that increase in harvested area could increase the production of sugarcane. The result of regression analysis also shows that increase in harvested area, rendemen, and rainfalls could increase the production of sugar, post amalgamation Bungamayang District and PT. Perkebunan Nusantara VII (Persero) could give better sugar production, while the increase in the number of labour would decrease the production of sugar because the number of labour has reached the maximum level. From the results of the study show that the highest profit of sugar and molasses in Bungamayang District PT. Perkebunan Nusantara VII (Persero) is the Ratoon Cane I cropping pattern, followed by Ratoon Cane II, Ratoon Cane III, and the lowest profit obtained in Plant Cane.
\end{abstract}

\section{Keywords: sugarcane, sugar, production, profit}

\section{INTISARI}

Penelitian ini dilaksanakan di wilayah Distrik Bungamayang, PT Perkebunan Nusantara VII (Persero), Provinsi Lampung. Penelitian ini bertujuan untuk: (1) Mengetahui trend produksi, produktivitas dan penggunaan input produksi tebu dan gula, (2) Mengetahui faktor-faktor yang mempengaruhi produksi tebu, (3) Mengetahui faktor-faktor yang mempengaruhi produksi gula, dan (4) Mengetahui tingkat keuntungan produksi gula dan tetes. Metode yang digunakan adalah deskriptif analisis. Metode penentuan lokasi dilakukan secara purposive sampling.Data yang digunakan adalah data sekunder selama kurun waktu 30 tahun (1984-2013). Metode analisis yang digunakan adalah analisis trend, regresi linier berganda (fungsi Cobb-Douglas), dan analisis keuntungan. Hasil analisis trend menunjukkan bahwa produksi gula, produktivitas gula, dan rendemen tebu memiliki trend yang positif, sedangkan jumlah tenaga kerja memiliki trend yang negatif. Hasil analisis regresi fungsi produksi tebu menunjukkan bahwa peningkatan luas panen dapat meningkatkan produksi tebu di Distrik Bungamayang PT. Perkebunan Nusantara VII (Persero). Hasil analisis regresi fungsi produksi gula menunjukkan bahwa peningkatan luas panen, rendemen tebu, jumlah curah hujan akan meningkatkan produksi gula dan setelah Distrik Bungamayang bergabung dengan PT. Perkebunan Nusantara VII (Persero) dapat memberikan produksi gula lebih baik. Peningkatan jumlah tenaga kerja akan menurunkan produksi gula dikarenakan jumlah tenaga kerja telah mencapai jumlah yang maksimum. Dari hasil penelitian juga diketahui bahwa keuntungan tertinggi dari produksi gula dan tetes di Distrik Bungamayang PT. Perkebunan Nusantara VII (Persero) adalah pada pola tanam Ratoon Cane I, diikuti oleh pola tanam Ratoon Cane II, Ratoon Cane III, dan Keuntungan terendah diperoleh pada tanaman Plant Cane.

Kata kunci : tebu, gula, produksi, keuntungan.

\section{PENDAHULUAN}

Indonesia memiliki potensi menjadi produsen gula dunia karena dukungan agroekosistem, luas lahan, dan tenaga kerja. Disamping itu prospek pasar gula di Indonesia cukup menjanjikan dengan konsumsi sebesar 4,2-4,7 juta ton/tahun. Gula merupakan salah satu kebutuhan pokok bagi masyarakat dan industri yang saat ini masih terus menjadi masalah karena masih terjadi kekurangan 
produksi dalam negeri, sementara kebutuhan gula masyarakat Indonesia terus meningkat (Dirjen Industri Agro dan Kimia Departemen Perindustrian, 2009).

Berdasarkan Angka Sementara tahun 2011 dari Direktorat Jenderal Perkebunan, luas areal tebu di Indonesia cenderung meningkat selama tahun 2000-2011. Perkebunan Rakyat (PR) mendominasi luas areal tebu, diikuti oleh Perkebunan Besar Swasta (PBS) dan Perkebunan Besar Negara (PBN). Tahun 2011 luas areal tebu Indonesia mencapai 457.615 ha atau hanya meningkat sebesar $0,77 \%$ dibandingkan tahun sebelumnya. Sentra produksi utama tebu pada tahun 2011 terdapat di 5 (lima) provinsi, yaitu Jawa Timur, Jawa Tengah, Lampung, Jawa Barat dan D.I. Yogyakarta dengan total kontribusi sebesar $98,9 \%$ terhadap total produksi gula di Indonesia. Jawa Timur berada di peringkat pertama dengan kontribusi sebesar $69,57 \%$ terhadap total produksi gula, sedangkan provinsi lain memberikan kontribusi kurang dari $20 \%$.

Berdasarkan data Direktorat Jenderal Perkebunan pada tahun 2011, Provinsi Lampung merupakan salah satu sentra produksi tebu nasional dengan menempati urutan ketiga sebagai provinsi sentra produksi tebu dengan memberikan kontribusi sebesar 6,73\%. PT. Perkebunan Nusantara VII (Persero) merupakan salah satu perusahaan yang bergerak dibidang perkebunan tebu yang berlokasi di Provinsi Lampung yaitu di Distrik Bungamayang, namun dalam jangka waktu tahun 2008-2012 produksi tebu sendiri di PT. Perkebunan Nusantara VII (Persero) cenderung mengalami penurunan yang dapat dilihat pada gambar 1 .
Aspek produksi merupakan salah satu aspek paling penting dalam suatu perusahaan. Besar kecilnya penerimaan dan keuntungan yang diterima oleh suatu perusahaan tergantung pada seberapa besar suatu produk mampu dihasilkan oleh perusahaan yang bersangkutan. Peningkatan produksi dan melaksanakan kegiatan produksi yang efisien penting dilakukan oleh setiap perusahaan, namun sebelum upaya-upaya peningkatan produksi tersebut dirumuskan maka terlebih dahulu perusahaan perlu mengetahui faktor-faktor apa saja yang mempengaruhi produksinya agar produksi yang diperoleh tinggi dan kegiatan produksi yang dilakukan berjalan secara efisien dan menguntungkan. Tujuan dari penelitian ini adalah:

1. Mengetahui trend produksi, produktivitas dan penggunaan input produksi tebu dan gula.

2. Mengetahui faktor - faktor yang mempengaruhi produksi tebu

3. Mengetahui faktor - faktor yang mempengaruhi produksi gula

4. Mengetahui keuntungan produksi gula dan tetes

\section{METODE PENELITIAN}

Menurut Wirartha (2006) metode deskriptif analisis adalah metode penelitian yang dilakukan untuk membuat gambaran mengenai pemecahan masalah yang aktual yang ada di masa sekarang. Metode deskriptif analisis merupakan metode yang memusatkan perhatian pada masalah masalah aktual yang ada pada masa sekarang. Data yang diperoleh mula-mula disusun, di jelaskan, kemudian dianalisis dan disajikan.

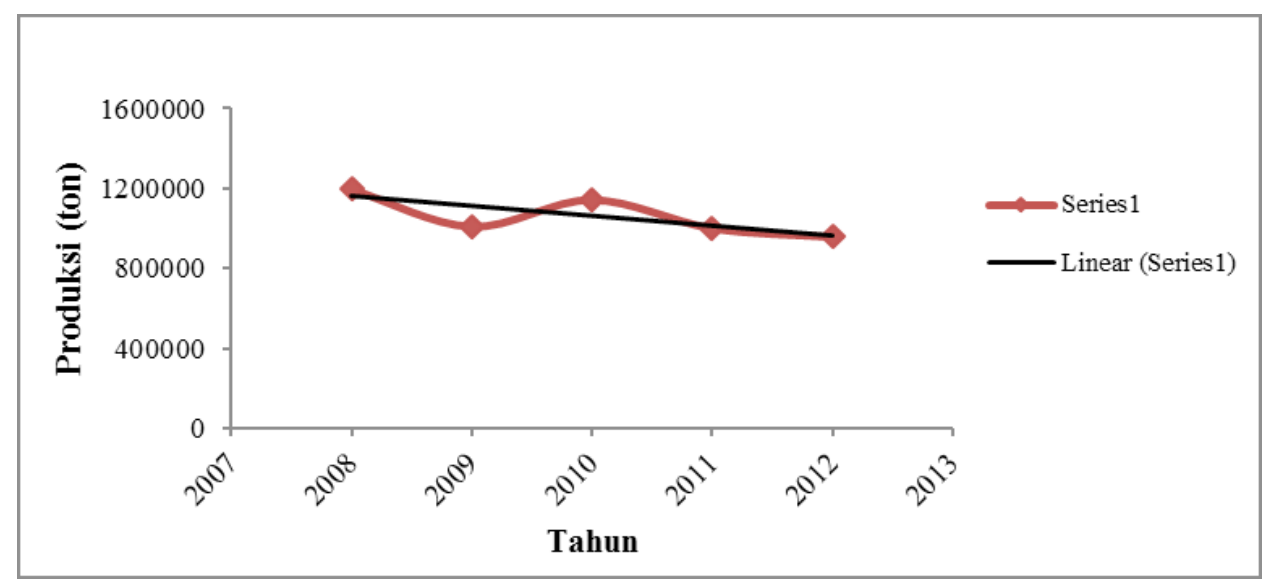

Gambar 1. Produksi Tebu PT. Perkebunan Nusantara VII (Persero) tahun 2008-2012. Sumber: PT Perkebunan Nusantara VII (Persero), 2014. 
Penelitian ini menggunakan data sekunder yang diperoleh langsung dari Distrik Bungamayang, PT. Perkebunan Nusantara VII (Persero). Data sekunder yang merupakan data time series (deret waktu) terdiri dari data-data output dan penggunaan input, biaya produksi dan harga output dalam kegiatan produksi di Distrik Bungamayang PT. Perkebunan Nusantara VII (Persero) dari tahun 1984-2013.

Analisis trend dapat digunakan untuk mengetahui perubahan nilai variabel dari waktu ke waktu. Analisis trend juga dimaksudkan untuk melihat kecenderungan tingkat produksi, produktivitas, dan penggunaan input produksi tebu dan gula di Distrik Bungamayang PT Perkebunan Nusantara VII (Persero) digunakan analisis trend dengan metode kuadrat terkecil (Least Square) dengan rumus sebagai berikut:

\section{Keterangan:}

$$
\mathrm{Y}=\mathrm{a}+\mathrm{bX}+e
$$

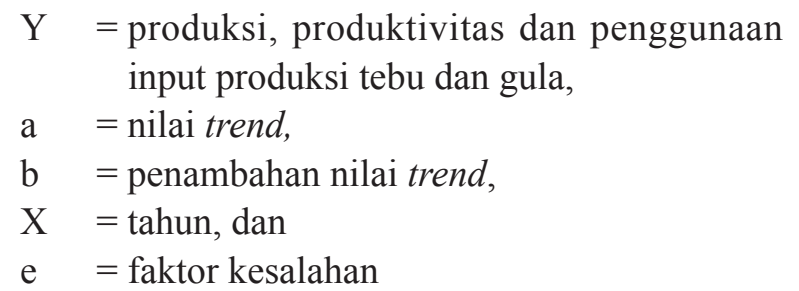

Uji t dilakukan untuk menguji pengaruh variabel bebas (waktu) terhadap variabel tidak bebas (produksi, produktivitas dan penggunaan input produksi tebu dan gula) (Gujarati, 2006).

Untuk mengetahui faktor-faktor yang mempengaruhi produksi digunakan metode fungsi Cobb-Douglas. Didalam mengestimasikan parameter fungsi produksi pada persamaan fungsi produksi Cobb-Douglas dipergunakan metode kuadrat terkecil yang biasa (OLS), sehingga estimasi untuk faktor- faktor yang memperngaruhi produksi tebu adalah sebagai berikut (Soekartawi, 2003):

$$
\begin{aligned}
\operatorname{Ln} Y= & \operatorname{Ln} \beta_{0}+\beta_{1} \operatorname{Ln} X_{1}+\beta_{2} \operatorname{Ln} X_{2}+\beta_{3} \operatorname{Ln} X_{3}+\beta_{4} \\
& \operatorname{Ln~} X_{4}+\beta D_{1}+\mu
\end{aligned}
$$

Keterangan:

$$
\begin{aligned}
& \mathrm{Y}=\text { Produksi tebu (ton) } \\
& \beta_{0}=\text { intersep } \\
& \beta_{1-} \beta_{5}=\text { koefisien regresi } \\
& \mathrm{X}_{1}=\text { Luas panen (ha) }
\end{aligned}
$$

$$
\begin{array}{ll}
\mathrm{X}_{2} & =\text { Curah Hujan (mm/th) } \\
\mathrm{X}_{3} & =\text { Hari Hujan (hari/th) } \\
\mathrm{X}_{4} & =\text { Tenaga Kerja (orang) } \\
\mathrm{D}_{1} & =\text { Dummy }
\end{array}
$$$$
\text { (sebelum bergabung PTPN VII }=0 \text { ) }
$$$$
\text { (setelah bergabung PTPN VII = 1) }
$$$$
\mu \quad=\text { faktor pengganggu }
$$

Untuk mengetahui faktor-faktor yang mempengaruhi produksi gula dipergunakan metode kuadrat terkecil yang biasa (OLS), sehingga estimasi untuk faktor- faktor yang memperngaruhi produksi gula adalah sebagai berikut

$$
\begin{aligned}
\operatorname{Ln} Y= & \operatorname{Ln} \beta_{0}+\beta_{1} \operatorname{Ln} X_{1}+\beta_{2} \operatorname{Ln} X_{2}-\beta_{3} \operatorname{LnX}_{3}-\beta_{4} \\
& \operatorname{Ln} X_{4}+\beta_{5} \operatorname{Ln} X_{5}+\beta D_{1}+\mu
\end{aligned}
$$

Keterangan:

$\mathrm{Y}=$ Produksi gula (ton)

$\beta_{0}=$ intersep

$\beta_{1-} \beta_{5}=$ koefisien regresi

$\mathrm{X}_{1}=$ Luas panen (ha)

$\mathrm{X}_{2}=$ Rendemen (\%)

$\mathrm{X}_{3}=$ Curah Hujan $(\mathrm{mm} / \mathrm{th})$

$\mathrm{X}_{4}=$ Hari Hujan (hari/th)

$\mathrm{X}_{5}=$ Tenaga Kerja (orang)

$\mathrm{D}_{1} \quad=$ Dummy

(sebelum bergabung PTPN VII $=0$ ) (setelah bergabung PTPN VII = 1)

$\mu \quad=$ faktor pengganggu

Sebelum dilakukan analisis regresi berganda, maka terlebih dahulu harus dilakukan uji normalitas dan uji asumsi klasik. Uji asumsi klasik bertujuan agar estimator-estimator yang diperoleh dengan motode Ordinary Least Square (OLS) memenuhi syarat Best Linier Unbiased Estimator (BLUE). Uji asumsi klasik yang dilakukan antara lain uji normalitas, multikolinearitas, autokorelasi, dan heteroskedastisitas (Gujarati, 2006).

Untuk menjawab tujuan keempat dilakukan analisis keuntungan perusahaan dengan menggunakan rumus (Suratiyah, 2011):

$$
\mathbf{T R}=\mathbf{P} . \mathbf{Q}
$$

Keterangan :

$\mathrm{TR}=$ Total Penerimaan

$\mathrm{P}=$ Harga Produk

$\mathrm{Q}=$ Jumlah produk 
Keuntungan perusahaan dapat diperoleh dari perhitungan hasil penerimaan dikurangi dengan biaya total, dengan rumus sebagai berikut:

$$
\pi=\mathbf{T R}-\mathbf{T C}
$$

Keterangan :

$\Pi=$ Keuntungan (profit)

$\mathrm{TR}=$ Total Revenue (Penerimaan)

$\mathrm{TC}=$ Total Cost $($ Total biaya $)$

\section{HASIL ANALISIS DAN PEMBAHASAN}

\section{Trend Produksi, Produktivitas dan Penggunaan Input Produksi Tebu dan Gula.}

Analisis trend digunakan untuk mengetahui pengaruh waktu sebagai variabel independen terhadap variabel dependen. Variabel dependen yang di gunakan dalam analisis trend masingmasing adalah produksi tebu, produktivitas tebu, produksi gula, produktivitas gula, rendemen tebu, luas panen, jumlah tenaga kerja, jumlah curah hujan, dan jumlah hari hujan.

Dari tabel 1 dapat dilihat bahwa tidak semua hasil analisis trend menunjukkan trend positif yang signifikan atau mengalami kenaikan. Hasil analisis trend yang menunjukkan trend positif adalah produksi gula, produktivitas gula, dan rendemen tebu, sedangkan untuk jumlah tenaga kerja memiliki trend yang negatif atau kecenderungan mengalami penurunan. Pada persamaan trend dengan variabel dependen produksi tebu, produktivitas tebu, luas panen, jumlah curah hujan, dan jumlah hari hujan menunjukkan hasil yang tidak signifikan sehingga dapat disimpulkan persamaan trend tidak dapat menunjukkan kecenderungan naik atau turun.

Salah satu penyebab fluktuasi produksi tebu yaitu dikarenakan jumlah luas panen yang di miliki juga mengalami fluktuasi. Faktor teknis budidaya yang mempengaruhi produktivitas tebu yaitu diantaranya penggunaan bibit dan juga kegiatan pemeliharaan tanaman tebu yang di laksanakan dikebun.

Produksi gula memiliki trend yang positif yang artinya produksi gula selama 30 tahun pengamatan terjadi kenaikan. Kenaikan produksi gula dapat di pengaruhi oleh nilai rendemen tebu yang di peroleh di Distrik Bungamayang PT. Perkebunan Nusantara VII (Persero). Rendemen tebu merupakan nilai kandungan kadar gula yang terdapat di batang tebu. Jika nilai rendemen naik maka produksi gula akan ikut mengalami kenaikan. Jumlah produksi gula mengalami kenaikan dikarenakan nilai rendemen yang mengalami kenaikan yang signifikan setiap tahunnya.

Meningkatnya produktivitas gula dapat dipengaruhi oleh semakin baiknya tingkat teknologi yang digunakan dalam kegiatan produksi gula. Salah satu faktor on farm yang ikut mempengaruhi produktivitas gula adalah persediaan air. Pada tahun 2013 produktivitas gula mengalami kenaikan di karenakan terjadi hujan yang merata di lahan tebu milik Distrik Bungamayang PT. Perkebunan Nusantara VII (Persero).

Untuk memperoleh rendemen yang baik, maka tebu harus di panen tepat waktu yaitu itu pada saat tebu telah mencapai tingkat kemasakan. Waktu yang baik yang disarankan untuk melakukan panen

Tabel 1. Rangkuman Hasil Analisis Trend

\begin{tabular}{llll}
\hline \multicolumn{1}{c}{ Trend } & \multicolumn{1}{c}{ Persamaan } & \multicolumn{1}{c}{ Sig, } \\
\hline Produksi Tebu & $\mathrm{Y}=497742-2525,1 \mathrm{X}$ & 0,0636 & $0,179^{\mathrm{ns}}$ \\
Produktivitas Tebu & $\mathrm{Y}=64,472+0,0468 \mathrm{X}$ & 0,0039 & $0,742^{\mathrm{ns}}$ \\
Produksi Gula & $\mathrm{Y}=23904+2148,7 \mathrm{X}$ & 0,6074 & $0,000^{* * *}$ \\
Produktivitas Gula & $\mathrm{Y}=3,1992+0,0651 \mathrm{X}$ & 0,4358 & $0,000^{* * *}$ \\
Rendemen Tebu & $\mathrm{Y}=4,9483+0,0951 \mathrm{X}$ & 0,4652 & $0,000^{* * *}$ \\
Luas Panen & $\mathrm{Y}=7763,4-43,814 \mathrm{X}$ & 0,0754 & $0,142^{\mathrm{ns}}$ \\
Jumlah Tenaga Kerja & $\mathrm{Y}=929,42-8,6251 \mathrm{X}$ & 0,7536 & $0,000^{* * *}$ \\
Jumlah Curah Hujan & $\mathrm{Y}=2596,1-10,597 \mathrm{X}$ & 0,0504 & $0,233^{\mathrm{ns}}$ \\
Jumlah Hari Hujan & $\mathrm{Y}=140,18+0,5279 \mathrm{X}$ & 0,0351 & $0,321^{\mathrm{ns}}$ \\
\hline Sum
\end{tabular}

Sumber: Analisis Data Sekunder,2014.

Keterangan:

$* * *=$ signifikansi $\alpha=0,01$

$* * \quad=$ signifikansi $\alpha=0,05$

$* \quad=$ signifikansi $\alpha=0,1$

ns $=$ tidak signifikan 
tebu yaitu pada saat musim kering sehingga kadar air yang ada di batang tebu akan menurun. Prinsip yang digunakan dalam kegiatan panen tebu adalah MBS (Manis, Bersih, dan Segar). Selain itu juga terdapat beberapa faktor yang dapat megakibatkan penurunan rendemen antara lain kegiatan tebang angkut tebu.

Lahan merupakan input produksi yang digunakan dalam kegiatan produksi. Lahan yang digunakan untuk budidaya tebu di merupakan lahan tebu sendiri yang berasal dari lahan HGU (Hak Guna Usaha). Salah satu yang menjadi penyebab turunnya luas panen tebu yaitu dikarenakan pada saat panen raya terdapat tanaman tebu yang tidak dapat dipanen sehingga di panen pada tahun yang akan datang. Hal tersebut terakhir terjadi di Distrik Bungamayang PT. Perkebunan Nusantara VII (Persero) pada tahun 2011. upaya peningkatan luas panen tebu yang dilakukan dengan cara menggunakan kembali lahan tidur atau lahan yang sudah lama tidak digunakan yang ada.

Distrik Bungamayang setelah bergabung dengan PT. Perkebunan Nusantara VII (Persero) terjadi penurunan jumlah tenaga kerja tetap. dikarenakan dilakukan pengurangan tenaga kerja. Hal yang menjadi latar belakang dalam penggabungan PG Bungamayang ke PT. Perkebunan Nusantara VII (Persero) yaitu penggabungan per wilayah.

Jumlah curah hujan dan jumlah hari hujan di Distrik Bungamayang PT. Perkebunan Nusantara VII (Persero) memiliki nilai yang fluktuatif. Untuk mengatasi kebutuhan air dengan keadaan jumlah curah hujan yang cenderung menurun yaitu dengan cara menggunakan sistem irigasi yang di gunakan untuk mengairi lahan tebu yang berasal dari kolam penampungan air hujan yang dibuat agar air hujan dapat dimanfaatkan secara optimal.

\section{Faktor-Faktor yang Mempengaruhi Produksi Tebu}

Data produksi tebu di PT Perkebunan Nusantara VII (Persero) digunanakan sebagai variabel dependen, sedangkan untuk variabel independen yang digunakan antara lain luas panen, jumlah curah hujan, jumlah hari hujan, jumlah tenaga kerja dan variabel dummy. Hasil analisis yang diperoleh melalui analisis regresi dapat dilihat pada tabel 2.

Dari hasil analisis regresi berganda dengan metode OLS diperoleh nilai Adjusted $\mathrm{R}^{2}$ sebesar 0,749 . Hal tersebut menunjukkan bahwa 74,9 $\%$ variasi atau perubahan produksi tebu dapat dipengaruhi oleh variasi atau perubahan luas panen, jumlah curah hujan, jumlah hari hujan, jumlah tenaga kerja, dan variabel dummy, sedangkan sisanya sebesar $25,1 \%$ dipengaruhi variabel lain diluar model. Berdasarkan hasil analisis dapat dilihat bahwa nilai $\mathrm{F}$ signifikansi adalah sebesar 0,000 yang lebih kecil dari tingkat kepercayaan 0,001 sehingga dapat disimpulkan bahwa variebel independen secara bersama-sama berpengaruh terhadap produksi tebu.

\section{a. Konstanta}

Berdasarkan hasil analisis dapat diketahui nilai konstanta yang diperoleh adalah sebesar 7,389

Tabel 2. Hasil Analisis Regresi Liner Berganda Fungsi Produksi Tebu

\begin{tabular}{lcrrr}
\hline \multicolumn{1}{c}{ Variabel Independen } & $\begin{array}{c}\text { Tanda } \\
\text { Harapan }\end{array}$ & Koefisien & $T_{\text {hitung }}$ & Sig, \\
\hline Konstanta & & $7,389^{* * *}$ & 4,000 & 0,001 \\
(Ln) Luas panen & + & $0,791^{* * *}$ & 7,955 & 0,000 \\
(Ln) Curah Hujan & + & $-0,150^{\text {ns }}$ & $-1,191$ & 0,245 \\
$(\mathrm{Ln})$ Hari Hujan & + & $0,045^{\text {ns }}$ & 0,332 & 0,743 \\
$(\mathrm{Ln})$ Tenaga Kerja & + & $-0,060^{\text {ns }}$ & $-0,252$ & 0,803 \\
Dummy & + & $-0,039^{\text {ns }}$ & $-0,777$ & 0,445 \\
\hline Adjusted $\mathrm{R}^{2}$ & & 0,749 & & \\
F sig, & & 0,000 & & \\
\hline
\end{tabular}

Sumber: Analisis Data Sekunder,2014.

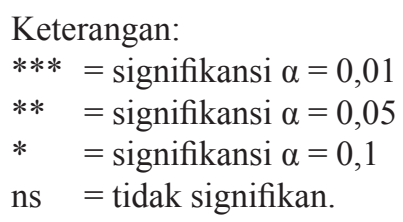


yang artinya apabila variabel independen lainnya dianggap tidak ada atau bernilai nol, maka besarnya nilai produksi tebu adalah sebesar Ln 7,389. Hasil analisis menunjukkan nilai signifikansi sebesar 0,001 lebih kecil dibandingkan dengan $\alpha=0,01$ sehingga dapat disimpulkan bahwa nilai konstanta berpengaruh terhadap produksi tebu

\section{b. Luas panen}

Luas panen memiliki pengaruh yang signifikan terhadap produksi tebu yaitu signifikan pada tingkat kesalahan 1\%. Angka koefisien regresi sebesar 0,791 menunjukkan bahwa kenaikan jumlah luas panen tebu akan berpengaruh positif terhadap produksi tebu dengan faktor lain dianggap tetap (cateris paribus). Hal tersebut menunjukkan bahwa setiap penambahan $1 \%$ luas panen tebu akan meningkatkan jumlah produksi tebu sebesar $0,791 \%$, yang artinya semakin luas panen tebu yang dilakukan maka jumlah produksi tebu akan meningkat.

\section{c. Curah hujan}

Jumlah curah hujan tidak memiliki pengaruh yang signifikan terhadap produksi tebu. Angka koefisien regresi sebesar $-0,150$ menunjukkan bahwa kenaikan jumlah curah hujan akan berpengaruh negatif terhadap produksi tebu dengan faktor lain dianggap tetap (cateris paribus). Variabel jumlah curah hujan tidak berpengaruh secara signifikan dikarenakan dalam kegiatan budidaya tebu (on farm) pihak perusahaan telah mengetahui waktu dan cara yang baik untuk kegiatan budidaya tebu sehingga masalah air dapat diatasi dengan baik pada saat kegiatan di kebun (on farm).

\section{d. Hari hujan}

Jumlah hari hujan tidak memiliki pengaruh yang signifikan terhadap produksi tebu. Angka koefisien regresi sebesar 0,045 menunjukkan bahwa kenaikan jumlah hari hujan akan berpengaruh positif terhadap produksi tebu dengan faktor lain dianggap tetap (cateris paribus). Variabel jumlah hari hujan tidak berpengaruh secara signifikan dikarenakan dalam kegiatan budidaya tebu (on farm) pihak perusahaan telah mengetahui waktu dan cara yang baik untuk kegiatan budidaya tebu sehingga masalah air dapat diatasi dengan baik pada saat kegiatan di kebun (on farm).

\section{e. Tenaga kerja}

Jumlah tenaga kerja tidak memiliki pengaruh yang signifikan terhadap produksi tebu. Angka koefisien regresi sebesar -0,060 menunjukkan bahwa kenaikan jumlah luas panen tebu akan berpengaruh negatif terhadap produksi tebu dengan faktor lain dianggap tetap (cateris paribus). Jumlah tenaga kerja tidak memiliki pengaruh yang signifikan terhadap produksi tebu, hal tersebut dikarenakan dalam kegiatan produksi faktor tenaga kerja lebih dipengaruhi oleh produktivitas tenaga kerja. Dalam produksi tebu lebih dibutuhkan tenaga kerja dengan produktivitas yang baik di bandingkan dengan jumlah tenaga kerjanya. Hal tersebut dikarenakan pada saat kegiatan budidaya (on farm) lebih membutuhkan tenaga kerja yang memiliki produktivitas yang tinggi.

\section{f. Dummy}

Variabel dummy tidak memiliki pengaruh yang signifikan terhadap produksi tebu baik pada saat Distrik Bungamayang sebelum bergabung dengan PT. Perkebunan Nusantara VII (Persero) maupun pada saat Distrik Bungamayang setelah bergabung dengan PT. Perkebunan Nusantara VII (Persero).

\section{Faktor-Faktor yang Mempengaruhi Produksi Gula}

Dalam analisis regresi liner berganda digunakan untuk mengetahui hubungan variabel dependen dengan beberapa variabel independen. Dalam analisis ini, data produksi gula di PT Perkebunan Nusantara VII (Persero) digunanakan sebagai variabel dependen, sedangkan untuk variabel independen yang digunakan antara lain luas panen, rendemen, jumlah curah hujan, jumlah hari hujan, jumlah tenaga kerja dan variabel dummy. Hasil analisis yang diperoleh melalui analisis regresi dapat dilihat pada tabel 3.

Dari hasil analisis regresi berganda dengan metode OLS diperoleh nilai Adjusted $\mathrm{R}^{2}$ sebesar 0,763 . Hal tersebut menunjukkan bahwa 76,3\% variasi atau perubahan produksi gula di Distrik Bungamayang PT. Perkebunan Nusantara VII (Persero) dapat dipengaruhi oleh variasi atau perubahan luas panen, rendemen, jumlah curah hujan, jumlah hari hujan, jumlah tenaga kerja, dan variabel dummy, sedangkan sisanya sebesar $23,7 \%$ dipengaruhi variabel lain diluar model. Berdasarkan 
Tabel 3. Hasil Analisis Regresi Liner Berganda Fungsi Produksi Gula

\begin{tabular}{lclrr}
\hline Variabel Independen & $\begin{array}{c}\text { Tanda } \\
\text { Harapan }\end{array}$ & \multicolumn{1}{c}{ Koefisien } & $\mathrm{T}_{\text {hitung }}$ & \multicolumn{1}{c}{ Sig, } \\
\hline Konstanta & & $10,418^{* *}$ & 2,169 & 0,041 \\
(Ln) Luas panen & + & $1,113^{* * *}$ & 4,490 & 0,000 \\
(Ln) Rendemen Tebu & + & $0,678^{* *}$ & 2,082 & 0,049 \\
(Ln) Curah Hujan & - & $0,687^{* *}$ & 2,116 & 0,045 \\
(Ln) Hari Hujan & - & $-0,438^{\mathrm{ns}}$ & $-1,343$ & 0,192 \\
(Ln) Tenaga Kerja & + & $-2,098^{* * *}$ & $-2,938$ & 0,007 \\
Dummy & + & $0,294^{* *}$ & 2,463 & 0,023 \\
\hline Adjusted R & & & & 0,763 \\
F sig, & & & & 0,000 \\
\hline
\end{tabular}

Sumber: Analisis Data Sekunder,2014.

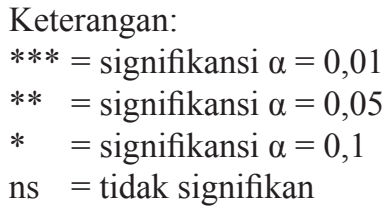

hasil analisis dapat dilihat bahwa nilai $\mathrm{F}$ signifikansi adalah sebesar 0,000 yang lebih kecil dari tingkat kepercayaan 0,001 sehingga dapat disimpulkan bahwa variebel independen secara bersama-sama berpengaruh terhadap produksi gula.

\section{a. Konstanta}

Nilai konstanta yang diperoleh adalah sebesar 10,418 yang artinya apabila variabel independen lainnya dianggap tidak ada atau bernilai nol, maka besarnya nilai produksi tebu adalah sebesar Ln 10,418. Hasil analisis menunjukkan nilai signifikansi sebesar 0,041 lebih kecil dibandingkan dengan $\alpha=0,05$ sehingga dapat disimpulkan bahwa nilai konstanta berpengaruh terhadap produksi gula di Distrik Bungamayang PT. Perkebunan Nusantara VII (Persero).

\section{b. Luas panen}

Luas panen memiliki pengaruh yang signifikan terhadap produksi gula yaitu signifikan pada tingkat kesalahan 1\%. Angka koefisien regresi sebesar 1,113 menunjukkan bahwa kenaikan jumlah luas panen tebu akan berpengaruh positif terhadap produksi tebu dengan faktor lain dianggap tetap (cateris paribus). Hal tersebut menunjukkan bahwa setiap penambahan $1 \%$ luas panen tebu akan meningkatkan jumlah produksi gula sebesar $1,113 \%$. Semakin luas panen tebu yang dilakukan maka jumlah produksi tebu akan meningkat dan produksi gula akan ikut meningkat. Hal tersebut dikarenakan tebu merupakan bahan baku utama dalam produksi gula.

\section{c. Rendemen}

Rendemen memiliki pengaruh yang signifikan terhadap produksi gula yaitu signifikan pada tingkat kesalahan 5\%. Angka koefisien regresi sebesar 0,678 menunjukkan bahwa kenaikan nilai rendemen akan berpengaruh positif terhadap produksi tebu dengan faktor lain dianggap tetap (cateris paribus). Hal tersebut menunjukkan bahwa setiap penambahan $1 \%$ nilai rendemen akan meningkatkan jumlah produksi gula sebesar 0,678 $\%$. Rendemen merupakan kadar kandungan gula yang terdapat pada batang tebu, jadi semakin tinggi rendemen yang dihasilkan maka produksi gula yang dihasilkan juga akan semakin tinggi. Hubungan antara rendemen dan produksi gula dapat dilihat nilai trend yang sama sama menunjukkan nilai yang positif, yang artinya kenaikan nilai rendemen akan menyebabkan kenaikan nilai produksi gula.

\section{d. Curah hujan}

Jumlah curah hujan memiliki pengaruh yang signifikan terhadap produksi gula yaitu signifikan pada tingkat kesalahan 5\%. Angka koefisien regresi sebesar 0,687 menunjukkan bahwa kenaikan jumlah curah hujan akan berpengaruh positif terhadap produksi gula dengan faktor lain dianggap tetap (cateris paribus). Hal tersebut menunjukkan bahwa setiap penambahan $1 \%$ jumlah curah hujan akan meningkatkan jumlah produksi gula sebesar $0,687 \%$. Hal tersebut tidak sesuai dengan tanda harapan dikarenakan jumlah curah hujan yang terjadi di lahan selama waktu pengamatan belum mencapai jumlah yang optimal, sehingga masih 
bisa terus ditingkatkan, namun sebaiknya pada masa pembentukan gula dibatang tebu jumlah hujan dikurangi atau di manajemen karena proses pembentukan gula di batang tebu membutuhkan kondisi lingkungan yang kering. Curah hujan rata-rata selama waktu pengamatan adalah sebesar $2431,81 \mathrm{~mm} /$ tahun. Tanaman tebu dapat tumbuh dengan baik pada daerah dengan curah hujan maksimal sebesar $3000 \mathrm{~mm} /$ tahun, sehingga masih dapat dilakukan upaya untuk meningkatkan curah hujan atau pemberian air bagi tanaman tebu agar produksi gula mencapai maksimal.

\section{e. Hari hujan}

Jumlah hari hujan tidak memiliki pengaruh yang signifikan terhadap produksi gula. Angka koefisien regresi sebesar -0,438 menunjukkan bahwa kenaikan jumlah hari hujan akan menurunkan produksi gula dengan faktor lain dianggap tetap (cateris paribus). Jumlah hari hujan tidak berpengaruh secara signifikan karena sudah dikembangkan kolam penampungan air hujan sehingga air dapat di kelola dengan baik di kebun.

\section{f. Tenaga kerja}

Jumlah tenaga kerja memiliki pengaruh yang signifikan terhadap produksi gula yaitu signifikan pada tingkat kesalahan 1\%. Angka koefisien regresi sebesar-2,098 menunjukkan bahwa kenaikan jumlah tenaga kerja akan berpengaruh negatif terhadap produksi gula dengan faktor lain dianggap tetap (cateris paribus). Hal tersebut menunjukkan bahwa setiap penambahan $1 \%$ jumlah tenaga kerja akan menurunkan jumlah produksi gula sebesar -2,098 $\%$, hal tersebut tidak sesuai dengan tanda harapan dikarenakan telah terjadi kelebihan jumlah tenaga kerja di wilayah Distrik Bungamayang, sehingga perlu adanya pengurangan jumlah tenaga kerja tetap dengan tujuan agar produktivitas tenaga kerja optimal sehingga dapat meningkatkan produksi gula.

\section{g. Dummy}

Berdasarkan tabel 3 variabel dummy memiliki pengaruh yang signifikan terhadap produksi gula yaitu signifikan pada tingkat kesalahan $5 \%$ yang menunjukkan bahwa ada perbedaan produksi gula pada saat Distrik Bungamayang sebelum bergabung dengan PT. Perkebunan Nusantara VII (Persero) dan pada saat Distrik Bungamayang setelah bergabung dengan PT. Perkebunan Nusantara VII (Persero).
Angka koefisien regresi sebesar 0,294 menunjukkan bahwa produksi gula di Distrik Bungamayang lebih baik setelah bergabung dengan PT. Perkebunan Nusantara VII (Persero). Peningkatan dapat disebabkan karena semakin naiknya nilai rendemen tebu di Distrik Bungamayang sehingga produksi gula juga akan semakin meningkat.

\section{Analisis Keuntungan}

Tujuan perusahaan adalah untuk memperoleh keuntungan yang sebesar-besarnya. Dalam penelitian ini dilakukan perhitungan keuntungan dari proses produksi di Distrik Bungamayang Tahun 2013. Komponen yang dihitung untung mengetahui besarnya keuntungan yang di peroleh Distrik Bungamayang pada tahun 2013 yaitu meliputi komponen penerimaan dan biaya produksi. Sumber penerimaan berasal dari produksi gula dan tetes yang di produksi di PG Bungamayang. Sedangkan untuk komponen biaya yang di keluarkan selama proses produksi di PG Bungamayang pada tahun 2013 yaitu meliputi biaya umum, biaya pembibitan, biaya kebun, biaya tebang muat angkut, biaya pabrik, dan biaya pengolahan. Hasil perhitungan keuntungan produksi PG Bungamayang pada tahun 2013 dapat dilihat pada tabel 4 .

Tabel 4. Keuntungan Produksi di Distrik Bungamayang Tahun 2013

\begin{tabular}{|c|c|}
\hline Penerimaan & Jumlah \\
\hline \multicolumn{2}{|l|}{ Gula } \\
\hline Produksi Gula (kg) & 38.151 .430 \\
\hline Harga Gula (Rp/kg) & 8.966 \\
\hline Penerimaan Gula & 342.065 .721 .380 \\
\hline \multicolumn{2}{|l|}{ Tetes } \\
\hline Produksi Tetes $(\mathrm{kg})$ & 24.472 .150 \\
\hline Harga Tetes $(\mathrm{Rp} / \mathrm{kg})$ & 945 \\
\hline Penerimaan Tetes & 23.126.181.750 \\
\hline Total Penerimaan (A) & 365.191 .903 .130 \\
\hline \multicolumn{2}{|l|}{ Biaya } \\
\hline Biaya Umum (Rp) & 25.092 .734 .700 \\
\hline Pembibitan (Rp) & 16.489.785.800 \\
\hline Biaya Kebun (Rp) & 79.331 .485 .425 \\
\hline Biaya Tebang dan Angkut (Rp) & 47.280 .111 .200 \\
\hline Biaya Pengolahan (Rp) & 38.769 .145 .441 \\
\hline Total Biaya (Rp) (B) & 206.963 .262 .566 \\
\hline Keuntungan (Rp) (A-B ) & 158.228 .640 .564 \\
\hline
\end{tabular}

Sumber: Analisis Data Sekunder, 2014.

Keuntungan dapat diperoleh dengan cara menghitung penerimaan total perusahaan dikurangi 
dengan biaya total. Besarnya keuntungan yang di peroleh Distrik Bungamayang pada tahun 2013 dapat dilihat pada tabel 4. Dari tabel 4 dapat dilihat bahwa hasil perhitungan penerimaan total produksi di Distrik Bungamyang pada tahun 2013 adalah sebesar Rp. 365.191.903.130, sedangkan untuk biaya total yang dikeluarkan Distrik Bungamayang untuk kegiatan produksinya pada tahun 2013 adalah sebesar Rp. 206.963.262.566. Dari perhitungan yang dilakukan makan diperoleh hasil bahwa keuntungan yang diterima Distrik Bungamayang pada tahun 2013 yaitu sebesar Rp. 158.228.640.564. Berdasarkan hasil perhitungan dapat dilihat bahwa penerimaan total memiliki nilai yang lebih besar dibandingkan dengan biaya total sehingga kegiatan produksi di Distrik Bungamayang memberikan keuntungan.

Di wilayah kebun tebu di Distrik Bungamayang PT. Perkebunan Nusantara VII (Persero) diterapkan dua pola tanam tebu yaitu pola tanam plant cane (tebu tanam) dan ratoon cane (tebu keprasan). Berikut ini dapat dilihat perbedaan keuntungan yang diperoleh pada masing masing pola tanam yang terdapat pada tabel 5 .

Tabel 5. Keuntungan Produksi Masing-masing Pola Tanam Tahun 2013

\begin{tabular}{lcc}
\hline \multicolumn{1}{c}{ Pola Tanam } & $\begin{array}{c}\text { Luas Lahan } \\
(\mathrm{Ha})\end{array}$ & Keuntungan (Rp) \\
\hline Plant Cane & 1839,35 & 24.534 .813 .680 \\
Ratoon Cane I & 2516,40 & 60.586 .904 .875 \\
Ratoon Cane II & 1771,20 & 40.821 .120 .755 \\
Ratoon Cane III & 1505,35 & 32.285 .801 .254 \\
\hline
\end{tabular}

Sumber: Analisis Data Sekunder, 2014.

Dari tabel 5 dapat dilihat bahwa terdapat perbedaan keuntungan dari produksi gula dan tetes pada masing- masing pola tanam yang di terapkan di Kebun Distrik Bungamayang. Keuntungan yang tertinggi hingga yang terendah secara berturut-turut adalah Ratoon Cane I, Ratoon Cane II, Ratoon Cane III, dan Plant Cane. Berdasarkan hasil analisis dapat disimpulkan bahwa tanaman tebu hingga keprasan ketiga (Ratoon Cane I-III) masih memberikan keuntungan lebih tinggi daripada tebu tanam (Plant Cane). Perbedaan ini disebabkan karena adanya penambahan biaya pada tanaman Plant Cane, yaitu berupa biaya bibit dan pupuk dasar yang tidak diberikan pada tanaman tebu keprasan (Ratoon Cane).

\section{KESIMPULAN}

1. Produksi gula, produktivitas gula, dan rendemen tebu di Distrik Bungamayang PT. Perkebunan Nusantara VII (Persero) memiliki trend yang positif.

2. Jumlah tenaga kerja di Distrik Bungamayang PT. Perkebunan Nusantara VII (Persero) memiliki trend yang negatif.

3. Peningkatan faktor produksi luas panen akan meningkat produksi tebu di Distrik Bungamayang PT. Perkebunan Nusantara VII (Persero).

4. Peningkatan faktor produksi luas panen, rendemen tebu, jumlah curah hujan akan meningkatkan produksi gula dan setelah PG Bungamayang bergabung dengan PT. Perkebunan Nusantara VII (Persero) dapat memberikan produksi gula lebih baik, sedangkan peningkatan jumlah tenaga kerja akan menurunkan produksi gula di Distrik Bungamayang PT. Perkebunan Nusantara VII (Persero)

5. Jumlah tenaga kerja tetap di wilayah Distrik Bungamayang PT. Perkebunan Nusantara VII (Persero) telah mencapai jumlah yang maksimum.

6. Keuntungan produksi gula dan tetes di Distrik Bungamayang dengan urutan tertinggi hingga terendah yaitu Ratoon Cane I, Ratoon Cane II, Ratoon Cane III, Plant Cane (PC).

\section{DAFTAR PUSTAKA}

Anonim, 2014. Data Produksi Tebu PT. Perkebunan Nusantara VII. <>. Diakses Pada 28 Maret 2014.

Direktorat Jenderal Industri Agro Dan Kimia Departemen Perindustrian. 2009. Roadmap Industri Gula. Departemen Perindustrian. Jakarta.

Direktorat Jenderal Perkebunan. 2011. Informasi Ringkas Komoditas Perkebunan. Pusat Data Dan Sistem Informasi Pertanian No. 02/01/I.

Gujarati, D N. 2006. Dasar-Dasar Ekonometrika. Penerbit Erlangga. Jakarta.

Suratiyah, K. 2011. Ilmu Usahatani. Penebar Swadaya. Jakarta

Wirartha, I M. 2006. Metodologi Penelitian Sosial Ekonomi. Penerbit Andi. Yogyakarta 